\title{
The Implementation Planning of Procurement Lecturers Based Islamic Boarding School
}

\author{
Apriyanti Widiansyah ${ }^{1}$, Sutjipto Sutjipto ${ }^{2}$, Mukhneri Mukhtar ${ }^{3}$ \\ \{apriyanti.widiansyah@dsn.ubharajaya.ac.id ${ }^{1}$, sutjipto17646@gmail.com², mukhneri@unj.ac.id ${ }^{3}$ \} \\ Universitas Negeri Jakarta, Indonesia
}

\begin{abstract}
The research aims to know the implementation planning procurement of lecturer based Islamic boarding school. Ethnographic studies conducted with case studies on the Institute Islamic Shalahuddin Al-Ayyubi in the Islamic boarding school El-Nur ElKasysyaf Bekasi West Java Indonesia. Research results planning procurement of lecturer based Islamic boarding school not inseparable from the policy coordinator the higher education of the religion of Islam, so that authorities of the College based Islamic boarding school only in determining the allocation of procurement lecturers and faculty based on the amount already approved by the Coordinator. Based on research, sighted in the Institute Islamic Shalahuddin Al-Ayyubi on the Islamic boarding school El-Nur ElKasysyaf Bekasi West Java Indonesia doing improved quality lecturers by setting some changes to qualifying skill. Change the skill qualification plan, could not be released from a venture change are planned, start of the process skills development diagnostic, mastering the strategy of relations in the form of the system as well as bringing together cultural. Priority planning procurement of lecturer not enough only with the appropriate skills course, but with regard to changes in the development of expertise, skills as well as attitudes resources the lecturers, so it is able to achieve the goal of higher education based Islamic boarding school, and can compete on a national and international level.
\end{abstract}

Keywords: Planning, Procurement Lecturer, Islamic boarding school

\section{Introduction}

In the Organization, human resources play an important role in determining the direction of progress and setbacks of the Organization, including human resources at colleges known as the professions of lecturer. Human resources management of colleges as part of the management of the whole civitas Academica. Challenge managers higher education to prepare professional lecturers, resources that are able to produce graduates competent in the field of science.

The conception of the human resource management higher education provide an understanding that lecturer resources have a vital position in the quality of college graduates in General. This position is strengthened by the fact that lecturer resources become a high authority in the academic process, even higher than similar professions in other educational institutions. For this reason, higher education human resources at the lowest to the highest level of leadership and education staff must be able to work to prepare the needs of the lecturers, innovate to find solutions, and maintain good relations. Recruitment is the process of gathering applicants who qualify for positions available in an organization[1] and decide whether to hire applicants who meet the requirements or reject it. Selection involves choosing 
the most suitable applicant to meet the requirements for a particular job. Selection practice is a decision making activity or calculation of psychological compatibility[2] Recruitment is the process of applicants who match the search criteria required by an organization [3].

Higher education human resource management is also able to become a motivator for lecturers, assisting lecturers to dare to face the challenges of education in the future, and make lecturers more valuable and meaningful, both for themselves and the surrounding environment. Therefore, the existence of professional lecturer resources becomes important in the environment of higher education organizations, because the lecturer profession is considered by the community as a noble profession, a scientific-based profession [4].

The presence and intelligence of lecturers have an important role and determine the success and smoothness of learning activities. trying to carry out the task properly and effectively, the lecturer is able to have the ability to motivate, discipline, ethics, culture, ethos and high moral.

Islamic boarding schools are one of the unique Islamic institutions with very strong characteristics. The role taken is the intellectual effort of the nation which has been passed down for generations. Islamic boarding schools also provide education in difficult times, the struggle against the colonial and is a center of study that has survived to this day. The aim of Islamic boarding schools education is not to pursue the interests of power, money and worldly grandeur, but instill the belief that learning is solely an obligation and a form of devotion to God. Therefore, as one of the educational institutions, Islamic boarding schools have a big responsibility in shaping the character of students. [5]

The study of innovation and modernization within the institution as a traditional institution connoted is interesting, because it contains four meanings. First, the study of innovation and modernization of relevant Islamic boarding schools in the context of the study of the characteristics of Indonesia, which is carrying out the development process. Second, Islamic boarding schools are a subculture of Islamic education in Indonesia, so innovation and modernization will provide unique colors. Third, the education of Islamic boarding schools is an ideal educational prototype for Indonesian people, because there is a rebalancing between cognitive, affective, and psychomotor domains. Fourth, observe Islamic boarding schools as traditional reform institutions (modernization). [6]

The development of Islamic boarding schools in Indonesia reaches 4,328 students with a total of more than 5 million people is a strength to be developed.[7] To carry out intellectual regeneration, Islamic boarding schools began to provide higher education services. this was based on the insistence of alumni and the wider community, so the pesantren established higher education to facilitate students to continue their studies at Islamic boarding schools.

The lecturer is based on the education and expertise appointed by the organizer of higher education with the main task of teaching in higher education. [8] Therefore, in improving the quality of Higher Education, a lecturer must receive more attention. The El-Nur El-Kasysyaf Islamic Boarding School in West Java, Indonesia, has been planning lecturer procurement activities based on the needs of lecturers form of recruitment of lecturers who must first obtain approval from the faculty Senate. Based on the background of the researchers eager to further examine how the implementation planning procurement of lecturer based Islamic Boarding School, case studies at Shalahuddin Al-Ayyubi Islamic Institute of Religion (INISA) in the Islamic boarding school El-Nur El-Kasysyaf Bekasi West Java Indonesia. 


\section{Method}

The research uses qualitative methodology, with ethnographic studies. Ethnographic models tend to lead to inductive, constructive, transferability, and subjective poles. Ethmography also describes existing cultures and traditions. Ethnography basically uses the participant observation data. This is in line with the notion of ethnographic terms derived from the ethno word (nation) and graphy (describing or describing). Ethnography is a variety of exposure to cultural research to understand how people interact and cooperate through phenomena observed in everyday life [9].

In this study, the researcher is the instrument of the research itself, where researchers are involved in the activity of collecting data which are then described in accordance with the data found in the field.As for the data collection technique used is form; 1 observation guidelines); 2) interview guidelines; 3) study of librarianship, and; 4) documentation. The research dataset can be accessed in https://osf.io/579st/ Open Science Framework in title of Data Collection Techniques, and documentations. The data are presented in Bahasa Indonesia.[10]

\section{Results and Discussion}

Human resource planning is the process of determining the movement of lecturers in the institution from the expected position in the future, while human resources is a set of processes and activities carried out jointly by the highest leadership of human resources and teaching staff to solve institutional problems related to lecturers. Therefore, human resource planning related to lecturer resources must be adapted to a specific strategy, so that the main objectives in facilitating the institution of effectiveness can be achieved. Future institutional strategies that are influenced by changes in environmental conditions require leadership to develop programs that are able to translate current problems and support the plan.[11].

Human resource planning is generally defined as the process of identifying the number of employees needed by the organization in terms of high quality and quantity, therefore it is seen as a continuous process of regular and structured planning. The main purpose of human resource planning is to ensure that employees have the best level of interaction on their work. Also, this planning process confirms that employees are in the right amount as required, namely there are no excesses and shortages of labor. [12].

Islamic boarding schools are religious institutions that organize community-based Islamic religious education or are integrated with other types of education, which aim to develop students' skills, knowledge and skills to become religious experts and have the skills to build Islamic life in society. [13] The emergence of learning models Islamic boarding schools, Islamic teachings are increasingly automatically spread on Java. Until it can be said that Islamic boarding schools are the spearhead of the spread of Islam to the people in Java.

Human resource planning, especially lecturers at INISA at the El-Nur El-Kasysyaf Islamic Boarding School in West Java, Indonesia, are prioritized to meet the needs of permanent lecturers in several faculties, because based on the analysis of interview results, one condition indicates that some faculties lack power permanent lecturers are very high when compared to the number of students there. The plan to add INISA permanent lecturers is determined through the mechanism of the Institute's Daily Leadership meeting, to discuss the number and qualifications needed. The decision of the meeting was then submitted to the Coordinator of Islamic Religion (the policy coordinator the higher education of the religion of 
Islam) to ask for approval on how many lecturers to be recruited, and usually the amount approved was far less than the amount proposed by INISA. The research dataset can be accessed in https://osf.io/579st/ Open Science Framework in title of The Findings of Field Data Based on The Results of The Interview, and the data are presented in Bahasa Indonesia.[10]

Based on some data sourced from domain analysis, it can be said that the planning of human resource procurement in INISA is inseparable from the policy of the Coordinator of Islamic Religion as an organizer, so the authority of INISA is only in determining the allocation of each faculty or study program Approved. The research dataset can be accessed in https://osf.io/579st/ Open Science Framework in title of Domain Analysis, and the data are presented in Bahasa Indonesia[10]

The pattern of recruitment of lecturers at INISA Bekasi, is carried out using 4 methods including; 1) Permanent recruitment of lecturers is done through acceptance of transfer people, which is to receive people from outside INISA who want to become lecturers in the INISA environment; 2) Lecturer recruitment through a contract system, namely by appointing several lecturers, who have certain skills, which are rare and very much needed, to be contracted as teaching staff or as leadership staff, within a certain period of time; 3) Lecturer recruitment is done by asking for help from higher education institutions, government institutions, or private institutions, to send resources that have certain skills to teach at INISA; 4) Lecturer recruitment is done by attracting lecturers from outside or inside the INISA campus themselves, to then be placed as non-permanent lecturers in each faculty with honorary lecturer status. The research dataset can be accessed in https://osf.io/579st/ Open Science Framework in title of The Methods of Recruitment of Lecturers, and the data are presented in Bahasa Indonesia[10]

Higher education as an educational institution has a very large role in efforts to develop human resources and improve national competitiveness, strategic roles and great efforts to run well, so human resources Higher education must have superior quality. Lecturers are human resources who have a central role in all activities in higher education.

Colleges should be able to manage and put human resources as the main component of the national program for the college program in order to achieve its vision and mission.[14] Human resources planning, particularly the lecturer, in a more prioritized INISA to meet the needs of lecturer remain on some of the faculty, because based on the analysis of the results of the interviews found a condition that showed that on some faculties experienced shorthanded lecturers remained very high if compared with the number of students that there are. Human resource procurement planning in INISA cannot be separated from the College's coordinator of policy on Islam as the organizers, so the authority only in determining the allocation of INISA on each faculty or courses based on the number of approved.

It was acknowledged that, the need for lecturers in the faculties and study programs could be overcome by recruiting non-permanent lecturers, but it should be remembered one thing that the status of permanent lecturers would indeed have a major influence on their role in developing academic in the campus environment. In reality, the irregular lecturers will usually go straight home after finishing teaching, even though the existence of lecturers is very much needed in the development of knowledge and intellectual development of students.

In addition, non-permanent lecturers are lacking in capacity, because coaching programs are aimed more at permanent lecturers, and even if they are built, their loyalty to remain in INISA also needs to be considered, because employees will devote their energy and loyalty to an organization, if the demands are fulfilled. 
Related to the explanation above, the conditions INISA in terms of compensation for nonpermanent lecturers, it seems that the loyalty and performance of non-permanent lecturers in INISA will be a problem, so it does not rule out the possibility of phenomena in and out of lecturers in filling INISA's need for lecturers, even though experience teaching is an indicator that is quite significant in determining the quality of a lecturer. As a boarding school-based higher education institution, having a permanent lecturer is certainly more profitable than having a non-permanent lecturer, because this will have implications for the amount of compensation costs that must be provided.

However, a plan to recruit non-permanent lecturers, while permanent lecturers are not yet available, it is also not wrong, especially the fixed lecturer quota for each study program is still limited by the policy coordinator the higher education of the religion of Islam who oversee religious colleges. Based on the quality, it can be seen that INISA is conducting an improvement in the quality of lecturer resources by establishing several changes in skills qualifications. Changes to the plan are in accordance with the understanding that organizational development cannot be separated from organizational change and development, namely a planned effort, initiated by experts through a process, to help an organization develop its diagnostic skills, relationship capabilities and strategies in the form of temporary and permanent systems and cultural equality.

\section{Conclusion}

Thus it appears that the implementation of the Islamic boarding schools-Based Lecturer Procurement Planning case study at INISA at El-Nur El-Kasysyaf Bekasi Islamic Boarding School is not only related to the addition of lecturers with appropriate expertise, but also related to changes and development of skills and attitudes of resources existing lecturers, so as to be able to achieve the objectives of INISA as universities Islamic boarding schools -based, to be able to compete at national and international level.

\section{Acknowledgement}

In the process of this research, researchers like to thank parents, husband, promoter and co-promoter, friend and also to the research place at Islamic religious Institute of Shalahuddin Al-Ayyubi (INISA) at boarding schools El-Nur El-Kasysyaf Bekasi. With the support whether maretial and non-materi that warehouse had beeb sent a researcher of the completion of this research.

\section{References}

[1] H. Mathis and L. Jackson, Human Resource Management. Singapore: Thomson Asia Pte . Ltd, 2004.

[2] A. Price, Human Resource Management in a Business Context., 2nd ed. London: Thomson Learning, 2004.

[3] K. M. Saifalislam, A. Osman, and M. . AlQudah, "Human Resource Management Practices: Influence of recruitment and selection, and training and development on the organizational 
performance of the Jordanian Public University,” IOSR J. Bus. Manag. (IOSR-JBM, vol. 16, no. May, 2014.

[4] Sasono Eko, "Manajemen Sumber Daya Manusia Perguruan Tinggi: Tantangan dan Kebutuhan,” J. Stie Semarang, vol. 6 NO 2, pp. 64-67, 2014.

[5] M. S. Zuhriy, "Budaya Pesantren dan Pendidikan Karakter Pada Pondok Pesantren Salaf," Walisongo, vol. 19, no. 2, pp. 287-310, 2011.

[6] M. Hasan, "Inovasi Dan Modernisasi Pendidikan Pondok Pesantren," KARSA J. Sos. dan Budaya Keislam., vol. 23, no. 2, pp. 295-305, 2015.

[7] U. Lugina, "Pengembangan Ekonomi Pondok Pesantren Di Jawa Barat," Risâlah, J. Pendidik. dan Stud. Islam, vol. 4, no. 1, pp. 53-64, 2017.

[8] I. Bastian, AKUNTANSI PENDIDIKAN. Yogyakarta: Erlangga, 2006.

[9] S. Endraswara, "buku Penelitian kualitatif." Pustaka Widyatama, Sleman, pp. 207-208, 2006.

[10] A. Widiansyah, "ataset Implementation Planning of Procurement Lecturers Based Islamic Boarding Schools," 2019. [Online]. Available: https://osf.io/579st/. [Accessed: 05-Jan-2019].

[11] R. Ritawati, "Perencanaan dan Pengembangan Guru/Dosen sebagai Sumber Daya Manusia (sdm) di Lembaga Pendidikan Formal,” J. Istinbath, vol. 16, pp. 109-123, 2015.

[12] H. D. Aslam, M. Aslam, N. Ali, B. Habib, and M. Jabeen, "Human Resource Planning Practice in Managing Human Resource : A Literature Review," Int. J. Hum. Resour. Stud., vol. 3, no. 1, pp. 200-212, 2013.

[13] I. Paturohman, "PERAN PENDIDIKAN PONDOK PESANTREN DALAMPERBAIKAN KONDISI KEBERAGAMAAN DI LINGKUNGANNYA (Studi Deskriptif pada Pondok Pesantren Dār Al-Taubah, Bandung)," Tarbawi, vol. 1, no. 1, pp. 65-74, 2012.

[14] A. Widiansyah, "Peranan Sumber Daya Pendidikan sebagai Faktor Penentu dalam Manajemen Sistem Pendidikan," Cakrawala Hum. Univ. Bina Sarana Inform., vol. 2 No. 2, no. 1, pp. 229234, 2018. 